\title{
Assessing the Impact of Salinity on Resource Use Efficiency in Wheat Production in Central Iraq
}

\author{
Mohammed J. Abdulradh \\ College of Agriculture, University of Baghdad, Baghdad, Iraq \\ Email: mohammed.abdulradh@uqconnect.ed.au \\ Boubaker Dhehibi, Osamah K. Jbara, and Kamel H. Shideed \\ International Center for Agricultural Research in the Dry Areas (ICARDA), Amman, Jordan \\ College of Agriculture, University of Baghdad, Baghdad, Iraq \\ Email: B.Dhehibi@cgiar.org, usamakadhim@yahoo.com, K.Shideed@CGIAR.ORG
}

\begin{abstract}
The objective of this study is to investigate the impact of salinity on resource use efficiency in wheat production in central Iraq using a cross-sectional database of 270 farmers. A parametric approach used to estimate a frontier of production. Stochastic Frontier analysis (SFA) is proposed for analysis resources use efficiency in irrigated wheat production system with respect to soil electric conductivity value. The results showed that, inputs such fertilizer and water were underutilized, while other inputs such as agricultural chemical, seed, labour, and mechanization were over-utilized. Based on scale elasticity value, yield of wheat could be increased by 13.9, 8.5, and $5 \%$ on average in low, moderate and, high soil salinity respectively, through the efficiency improvement of inputs use. Thus, soil salinity reduction plan for reclaimed, semireclaimed, and un-reclaimed need to be established in order to increase resources use efficiency and productivity in the Iraqi irrigated wheat areas.
\end{abstract}

Index Terms-salinity, resource use efficiency, wheat, Iraq, Stochastic Frontier Analysis (SFA), Electric Conductivity (EC), scale elasticity

\section{INTRODUCTION}

In arid and semiarid regions dissolved salts (salinity) in irrigation water are resulting serious environmental and economic issues for agricultural regions where the salt left behind in the soil after irrigation water evaporated [1] Salt-induced land degradation is a major constraint for agricultural production and the environment. According to the Food and Agriculture Organization of the United Nations (FAO) estimates, approximately $75 \%$ of the total irrigated area of Iraq (more than 2 million ha) is moderately saline and another $25 \%$ has levels of salinity that have converted once productive lands into saltaffected wastelands. Salinity and water logging are responsible for loss of cultivated lands in Iraq by $5 \%$ annually [2].

About $42 \%$ of equipped for irrigation areas have a moderate level of salinity, while $14 \%$ has a sever level of salinity ${ }^{1}$. In the face of that, the water level in the Tigris river has been fallen by more than $60 \%$ over the past 20 years, agricultural sector is the main sector in terms of water consumption in which $85 \%$ of water resource are used for agricultural purposes, due to soil salinity-fallow practices, and the unstable political situation, it is estimated that only $2.8-4.9$ million ha is actually cultivated annually. Soil salinity explains up to $50 \%$ of lost agricultural productivity in saline-affected areas [2], [3].

One of the important factors that lead to low crops productivity in Iraq is salinity. This situation is particularly critical for the irrigated areas in Iraq, which produces an important share of crops for the country [4]. In Iraq, many studies have been focused on the relationship between agricultural productivity and salinity of irrigation water, but, from publication stand point, the relationship between agricultural productivity and soil salinity have been ignored. Researches on impact of salinity on resource use efficiency are done in many parts of the world, however in Iraq, where the first ancient records of salinity effects were found, the researches on the impact of salinity on resource use efficiency are rare. Additionally, researches on resources use efficiency in wheat production in the irrigated region in central Iraq are limited.

The objective of the study is to investigate how farmers could re-allocate their resource in efficient and sustainable ways to produce sustainable agricultural production in the salt-affected areas of Iraq. Thus, this research aims to estimate the current situation with corresponding soil salinity level at different selected areas at farm level by analyzing resource use efficiency in wheat production in irrigated cropping systems and estimating technical and allocative efficiencies of the selected wheat farms with respect to soil salinity level. The fact that wheat farmers reach different levels of economic efficiency is a hypothesis need to be tested and whether soil salinity reduces the economic efficiency and 
increases resources use inefficiency of wheat farmers in the study area.

\section{A. Impact of Salinity on Resource Use Efficiency: Setting the Scene}

Ref. [5] represented that when the crop production is inefficient, it's useless to introduce a new technology unless farmer reach their maximum efficiency in used inputs. Boosting agricultural growth in strategic crops, in which wheat is on the top of the most important cropping list, is not require imposing new technologies only, but its initially require improving resource use efficiency of wheat farmers as well.

A stochastic frontier model used to measure the technical efficiency of date farms in Southern Tunisia where 282 farmers were interviewed. The study found that date productivity affected negatively by the independent variable (water salinity) [6].

In Sri Lanka, Mahaweli River System H Irrigation Scheme was investigated by Thiruchelvam, and Pathmarajah. They collected data from two irrigation projects (Nochchiyagama and Madatugama) where 90 and 110 farmers randomly selected, and found that 55\% of productivity losses was due to salinity, and also they found that, more inputs quantities were used in salinity affected region compare with moderately saline region [7].

Using Cobb-Douglas production function to estimate resource use efficiency in different crops production in saline irrigated environment in India, scholars examined 30 household during the period 2000-2004, They found that, the resource use inefficiency in wheat production season when irrigation was over utilized in saline environment, while other inputs were underutilize [8].

\section{B. Sampling and Data Collection}

\section{1) Study area}

Fig. 1 shows the targeted study area which is Wasit province in Iraq. This region represents one of the provinces (or governorates) in central of Iraq with total area of 1763380 ha which accounts for $3.9 \%$ of Iraqi area.

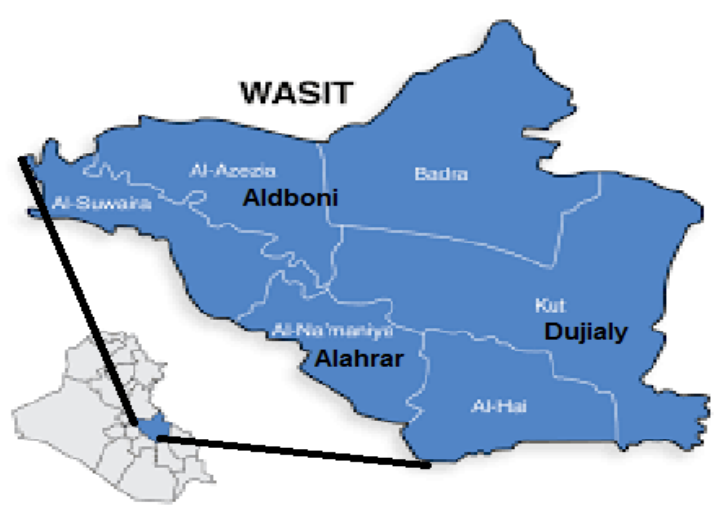

Figure 1. A map of study area

Table I shows area of Wasit province classification where about $61 \%$ of total areas are cultivatable. Moreover, $45 \%$ of cultivatable areas are salt effected land. Irrigated winter wheat is a dominant crop in the region with total cultivated area 236306 ha which accounted for about $20.9 \%$ of Iraqi irrigated area. Wasit province is the second largest province in wheat production in terms of cultivated area, and the first one in wheat production in terms of irrigated area. Wasit province contributes to total wheat production in Iraq by $21.9 \%$ [9].

TABLE I. AREA of WASit PRovince ClassificAtion (HA)

\begin{tabular}{|c|l|l|c|c|}
\hline \multirow{2}{*}{$\begin{array}{c}\text { Class } \\
\text { of area }\end{array}$} & \multirow{2}{*}{ Un-cultivatable } & \multicolumn{3}{|c|}{ Cultivatable } \\
\cline { 3 - 5 } & Reclaimed & $\begin{array}{c}\text { Semi- } \\
\text { reclaimed }\end{array}$ & $\begin{array}{c}\text { Un- } \\
\text { reclaimed }\end{array}$ \\
\hline $\begin{array}{c}\text { Area } \\
\text { ha }\end{array}$ & 704532 & 118199 & 37038 & 903611 \\
\hline \multicolumn{3}{|l}{ Source: [9] }
\end{tabular}

2) Data collection

The stratified random sampling technique used. Household survey on wheat farmers for 2015-2016 production season was conducted in three districts (Aldboni, Alahrar, and Dujialy). Multi-stage sampling technique and Stevin Thomson $\mathrm{Law}^{2}$ were used to calculate the sample size which was 270 households. Working with wheat farmers at Aldboni, Alahrar, and Dujialy districts, where 270 household were interviewed and soil and water samples were collected and analyzed. Based on secondary data assessment on the impact of salinity on wheat production and the share of wheat production, three districts have been selected in first stage: We select one district from each level of cultivable land in which affected by salinity. In addition, the selected districts have large share of wheat production as well, and geographical location was taken into the count based on the district location with respect to the Tigris River. Aldboni district is localized in the upstream while Dujialy district is on the downstream and Alahrar district in the middle. In the second stage, we classify each district based on agricultural land type (1: Un-reclaimed land, 2: Un-reclaimedland located on the main river, 3: Semireclaimedland and 4: Reclaimedland). Only the villages totally inside each type have been included in the survey. In the third stage, a random sample in each selected village was used to select randomly farmers of wheat proportionally to the sample size of each district.

\section{METHODOLOGICAL FRAMEWORK}

One technique of estimating a farm's relative position to the frontier used in this empirical study. SFA approach used to estimate the technical efficiency level of wheat producers and the sources of inefficiency. The theoretical model of a SFA is defined by:

$$
y_{i}=f\left(x_{i} ; \beta_{i}\right) \exp \left(v_{i}-u_{i}\right)
$$


$y_{i}=$ output of the ith farm, $f($.$) is an appropriate function$ $\mathrm{x}_{\mathrm{i}}$ is vector of input used by the ith farm, $\beta_{\mathrm{i}}$ is a vector of the unknown parameter to be estimated $i=1.2 .3 \ldots \ldots \ldots . . . n$ (Number of farms), $v_{\mathrm{i}}$ is a random error which accounts for random variations in output because of factors out of the farmers' control such as weather, measurement error, etc.

$\mathrm{u}_{\mathrm{i}}$ is a non-negative random variable representing inefficiency in output relative to the stochastic frontier.

The error component $\mathrm{v}_{\mathrm{i}}$ is assumed to be independently and identically distributed as $N\left(0, \sigma_{v^{2}}\right)$ were particularly concerned about the case of $\mathrm{u}_{\mathrm{i}}$ where is derived from a distribution $\mathrm{N}\left(0, \sigma_{\mathrm{u}^{2}}\right)$ truncated at zero (i.e. an exponential or half normal distribution) [10], while Ref. [11] considered only the case of Ui which has an exponential distribution. Estimating the TE of an individual farmer is defined in terms of the ratio of observed output to the corresponding frontier output with constant technology.

$$
\begin{gathered}
\mathrm{TE}=\frac{\mathrm{Y}_{\mathrm{i}}}{\mathrm{Y}_{\mathrm{i}^{*}}} \\
\mathrm{TE}=\frac{\mathrm{f}\left(\mathrm{x}_{\mathrm{i}} ; \beta_{\mathrm{i}}\right) \exp \left(\mathrm{v}_{\mathrm{i}}-\mathrm{u}_{\mathrm{i}}\right)}{\mathrm{f}\left(\mathrm{x}_{\mathrm{i}} ; \beta_{\mathrm{i}}\right) \exp \left(\mathrm{v}_{\mathrm{i}}\right)} \\
\mathrm{TE}=\exp \left(-\mathrm{u}_{\mathrm{i}}\right)
\end{gathered}
$$

The process of estimating TE is a one-stage process. The first step involves measuring the efficiency/inefficiency value using a normal production function. Using a suitable model to determine the socioeconomic factors that affected the efficiency value is second stage. The following Cobb-Douglas was estimated for the wheat crop in the study area (Wasit province) of Iraq.

$$
\begin{array}{r}
\ln Y_{i}=\beta_{0}+\beta_{1} \ln X_{1}+\beta_{2} \ln X_{2}+\beta_{3} \ln X_{3}+ \\
\beta_{4} \ln X_{4}+\beta_{5} \ln X_{5}+\beta_{6} \ln X_{6}+\beta_{7} \ln X_{7}+v_{i}-u_{i}
\end{array}
$$

The dependent variable, $Y_{i}$ is a yield of wheat, measure in kilogram per hectare $(\mathrm{Kg} / \mathrm{ha})$, and $\mathrm{X}_{1}$ is a number of Irrigation (NOI) during the cultivation season measure in number; $\mathrm{X}_{2}$ is agricultural chemical which is quantity of chemical pesticides $(\mathrm{CH})$ measure in liters per hectare (lit/ha); $\mathrm{X}_{3}$ is a fertilizer (FER) used in wheat production measure kilograms per hectare $(\mathrm{kg} / \mathrm{ha}) ; X_{4}$ is quantity of seed (SQ) used measure in kilograms per hectare $(\mathrm{kg} / \mathrm{ha})$; $\mathrm{X}_{5}$ is Labors quantity (L) employed during the season of wheat production, measure in man-days per hectare (man-days/ha); $\mathrm{X}_{6}$ is mechanization (M) in wheat production measure in machine-hours per hectare (Machhours/ha); $\mathrm{X}_{7}$ is an electric conductivity of soil (SEC) samples of farm measure in $\left(\mathrm{dS} \mathrm{m}{ }^{-1}\right)$.

The maximum likelihood method was used to estimate the impact of these socio-economic factors on technical efficiency of the farmers, The Maximum Likelihood Estimations (MLEs) model is specified as:

$$
\begin{gathered}
\text { ui }=\sigma_{0}+\sigma_{1} z_{1}+\sigma_{2} z_{2}+\sigma_{3} z_{3}+\sigma_{4} z_{4}+\sigma_{5} z_{5}+ \\
\sigma_{6} z_{6}+\sigma_{7} z_{7}
\end{gathered}
$$

$\sigma_{1}, \sigma_{2}, \sigma_{3} . \sigma_{7}$ Unknown parameters to be estimated

To determine the under or over utilization of each inputs, marginal value of product (MVP) to marginal factor cost (MFC) ratio for each input was used. The resource use efficiency parameter for each input was measured through using efficiency coefficient " $r$ " in which, if $r$ value is equal to one this imply that input was used efficiently, otherwise that input was used inefficiently. The inefficient use of an input could be in one of two scenarios. One is an input underutilization scenario indicated by $r$ value; if $r$ value is more than 1 in such case output level could be increase by increasing this input quantity. Second, is an input overutilization scenario, when the value of $r$ of an input is less than 1 this implies that, this input was overutilized, and output could be maximized with less quantity of this input [12]. This approach used in many countries, for example:

Ghana was divided into four agro-ecological zones, to find out resource use efficiency in maize production. A multi-stage sampling technique was employed to select 576 Maize farmers randomly. Qualitative technique used to determine the socio-economic characteristics of interviewed households, and output-inputs futures. While, quantitative ones, on one hand Stochastic Frontier Production Function used to estimate technical efficiency level, on the other hand, ratio of MVP to MFC presented the resources use efficiency coefficient of maize famer. The results showed that, if fertilizer quantity increases by $10 \%$ the maize yield will increase by $4.85 \%$, holding other factors constant. This situation is also true for other inputs such as herbicide; seed, and land, yield will increase by $1.77 \%, 7.34 \%$, and $11.45 \%$ respectively as well. Fertilizer, herbicide, pesticide, seed, and land were used in inadequate quantities, while labor, and capital were overused by 20.8 and $81.7 \%$ respectively [13].

Ref. [14], studied resource use efficiency in yam production in Nigeria, where 150 yam producers selected randomly from 5 Local Government Areas (LGAs). Using three types of function forms, namely Linear, Semi-log, and Cobb-Douglas, the results show that, inputs like, land, labour, and seed were underutilized, in which ratio of MVP and MFC is greater than one.

\section{RESULTS AND DISCUSSION}

\section{A. Qualitative Anaylsis}

The socio-economic characteristics of wheat farmers, who interviewed in the research, have been presented in Table II which presents descriptive statistics of quantities

\footnotetext{
${ }^{3} \mathrm{Z} 1=\mathrm{EC}$ of soil (Dummy: $1=$ less than $7.5 \mathrm{dS} \mathrm{m} \mathrm{m}^{-1}, 0=$ for equal or more than $7.5 \mathrm{dS} \mathrm{m}^{-1}$ )

$\mathrm{Z} 2=$ Farm location (dummy: 1 for main river, 0 sub-river).

$\mathrm{Z} 3=$ Experience (years).

$\mathrm{Z} 4=$ Educational level dummy: 0 for primary school or less, 1 for secondary school or more

$\mathrm{Z} 5=$ Position of farm (LF) (dummy: 1 in irrigation project and 0 for not) $\mathrm{Z} 6=$ Wheat share (wheat cultivated land /total cultivated land) $\%$. Z7 = Seed variety (Dummy: 0 IPA99, 1others)
} 
of inputs used and output. The mean value of yield on wheat in study area was around $2856 \mathrm{~kg} / \mathrm{ha}$. From the input side, the number of irrigation during wheat growing season was record as maximum irrigation as 7 times in some farms, while the mean value of number of irrigation was 4 times. The mean value of agricultural chemicals was $0.98 \mathrm{~L} /$ ha, applied in study area. Fertilizer and seed used with mean value of $292 \mathrm{~kg} / \mathrm{ha}$, and $249 \mathrm{~kg} / \mathrm{ha}$, respectively.

In fact, Table III shows the maximum labour work per hectare was 12.5 days in the season, with mean value of 6.03 man-days/ha. Moreover, the one hectare of wheat was requiring an average of mechanization working for 7.47 hours during production season of wheat. Soil testing laboratory provided the research with soil EC results which are included in Table III. In total samples, EC analysis indicates an average of EC around 3.69dS $\mathrm{m}^{-1}$.

Interviewed farmers have had on average 32 years of agricultural experience in irrigated wheat production. Finally, wheat crop had the largest share of cultivated area in the winter season compare with barley. The mean value of wheat share was $93 \%$ of cultivated areas in winter season were totally planted with wheat crop.

TABLE II. Descriptive Statistic OF QUANTITIES OF INPUTS AND OUTPUT

\begin{tabular}{|c|l|l|l|l|}
\hline Variable & Mean & St.D & Min. & Max. \\
\hline Yield ( Kg/ha) & 2856.8 & 1135.1 & 600 & 6400 \\
\hline $\begin{array}{c}\text { No. of Irrigation; NOI } \\
\text { (number) }\end{array}$ & 4.10 & 0.85 & 2 & 7 \\
\hline $\begin{array}{c}\text { Agricultural } \\
\text { Chemicals }{ }^{\mathrm{C} H} \text { ( L/ha) }\end{array}$ & 0.98 & 0.64 & 0.1 & 2.8 \\
\hline Fertilizer; Fer( Kg/ha) & 292.25 & 97.71 & 100 & 600 \\
\hline Seed; SQ( Kg/ha) & 249.53 & 46.73 & 160 & 400 \\
\hline Labour;L (Man-Days/ha) & 6.03 & 1.58 & 3.5 & 12.5 \\
\hline $\begin{array}{c}\text { Mechanization; M } \\
\text { (Mach -hours/ha) }\end{array}$ & 7.47 & 0.74 & 5.3 & 9.5 \\
\hline $\begin{array}{c}\text { Electric Conductivity; } \\
\text { EC (dS m }{ }^{-1} \text { ) }\end{array}$ & 3.69 & 3.64 & 0.42 & 17.87 \\
\hline Experience (years) & 32.55 & 10.87 & 10 & 63 \\
\hline Wheat share \% & 0.93 & 0.14 & 0.33 & 1 \\
\hline
\end{tabular}

Source: own elaboration from survey data (2017)

Based on soil salinity level ${ }^{5}$, salinity impacts on resource use and productivity are presented in Table IV. Table IV presents the descriptive statistics with respect to average values of recourses used and productivity.

Table III introduces a basic idea about the soil salinity effects on inputs used in wheat production. The mean value of yield reduced remarkable by $54.52 \%$ when the level of soil salinity change from $S_{1}$ to $S_{3}$.

\footnotetext{
${ }^{4}$ Agricultural chemicals are also known as pesticides and include herbicides and fungicides.

${ }^{5}$ Based on EC (Electric Conductivity) of the soil in the root zone, Irrigation water classification could be classified into three main classes

a- $\quad \mathrm{S}_{1}$ is refer to LS (Low Salinity) less than $2.5 \mathrm{dS} \mathrm{m}^{-1}$

b- $\quad \mathrm{S}_{2}$ is refer to MS (Medium Salinity) $2.5-7.5 \mathrm{dS} \mathrm{m}^{-1}$

c- $\quad \mathrm{S}_{3}$ is refer to HS (High Salinity) higher than $7.5 \mathrm{dS} \mathrm{m}^{-1}$
}

While in the inputs side the scenario is opposite in some cases, for instance, in Table IV average quantity of fertilizer and seed, used by farmers in $\mathrm{S}_{3}$ were more than those quantities used by farmers in $\mathrm{S}_{1}$ by $12 \%$ and $3.5 \%$ respectively.

TABLE III. IMPACT OF SALINITY ON RESOURCE USE AND PRODUCTIVITY

\begin{tabular}{|c|c|c|c|}
\hline \multirow{2}{*}{$\begin{array}{c}\text { Variables } \\
\text { (Mean) }\end{array}$} & \multicolumn{3}{|c|}{ Salinity level } \\
\hline & $\mathrm{S}_{1}$ & $\mathrm{~S}_{2}$ & $\mathrm{~S}_{3}$ \\
\hline Yield & 3466 & 2413 & 1576 \\
\hline NOI & 4.23 & 3.91 & 4 \\
\hline $\mathrm{CH}$ & 1 & 0.97 & 1 \\
\hline FER & 286 & 286 & 325 \\
\hline SQ & 244 & 256 & 253 \\
\hline $\mathrm{L}$ & 6 & 5.98 & 6.12 \\
\hline M & 7.34 & 7.44 & 7.6 \\
\hline $\mathrm{EC}$ & 1.21 & 4.45 & 10.85 \\
\hline
\end{tabular}

Source: own elaboration from survey data (2017)

Fig. 2 shows the relationship between soil salinity and yield for each farm. The said figure shows that only farms belongs to $S_{1}$ category produced yield more than 4000 $\mathrm{kg} / \mathrm{ha}$, and farms in $\mathrm{S}_{3}$ category could not produce yield more than $1576 \mathrm{~kg} / \mathrm{ha}$.

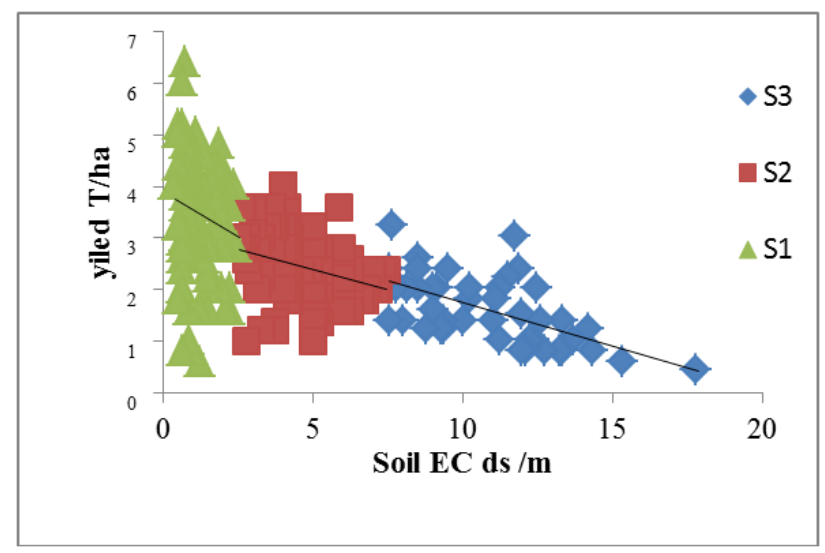

Figure 2. Yield and soil EC relationship

\section{B. Quantitative Analysis}

The remarkable changes in resource use efficiency and productivity connecting to the soil salinity level, from econometric perspective are presented in Table IV. Its show the results of stochastic frontier Cobb-Douglas production function analysis for wheat farmers.

The stochastic frontier production function analysis for wheat farmers estimated that, number of irrigation has significant positive effects on yield. Likewise, fertilizer has a significant positive effect on yield. Holding other factors constant, farmers in study area can increase yield through increases number of irrigation and quantities of fertilizer. However, Soil EC has significant negative effects on yield.

\footnotetext{
${ }^{6}$ Acronyms and units are the same in Table II
} 
TABLE IV. MAXIMUM LiKELIHOOD OF ESTIMATES OF STOCHASTIC FRONTIER PRODUCTION FUNCTION

\begin{tabular}{|c|l|}
\hline Variable & Coefficient \\
\hline Constant & 7.56 \\
\hline $\ln \boldsymbol{N O I}$ & $0.20^{* * *}$ \\
\hline $\ln \boldsymbol{C H}$ & -0.004 \\
\hline $\ln \boldsymbol{F E R}$ & $0.09 * *$ \\
\hline $\ln \boldsymbol{S} \boldsymbol{Q}$ & -0.02 \\
\hline $\ln \boldsymbol{L}$ & -0.02 \\
\hline $\ln \boldsymbol{M}$ & 0.10 \\
\hline $\ln \boldsymbol{S E C}$ & $-0.22^{* * *}$ \\
\hline Inefficient model & \\
\hline variable & $-0.33^{* *}$ \\
\hline EC & 0.08 \\
\hline Location & 0.00 \\
\hline Experience & 0.11 \\
\hline Education & $-1.35^{* * *}$ \\
\hline Position & 0.18 \\
\hline Wheat share & 0.13 \\
\hline Variety & $0.34 * * *$ \\
\hline $\boldsymbol{\sigma} \boldsymbol{2}$ & $0.96^{* * *}$ \\
\hline $\boldsymbol{\gamma}$ & \\
\hline
\end{tabular}

The asterisks indicates levels of significant: $* * *$ is significant at $1 \%$ level; ** is significant at $5 \%$ level; * is significant at $10 \%$ level.

There were two main sources of inefficiency and both are related to soil salinity, the first was EC of soil. If EC of soil is reduced less than $7.5 \mathrm{dSm}^{-1}$, this leads to reduce the technical inefficiency. The second source was the localization of the farm in which if farmer cultivated their wheat in reclaimed land, they will be more technically efficient.

\section{Resource Use Efficiency}

Based on these results, Table $\mathrm{V}$ shows, classification of efficiency coefficient ' $r$ ' value for each input used in wheat production in the study area. Taking into account the salinity level, farms classified into three zones $S_{1}, S_{2}$, and $S_{3}$, and $r$ value for each zone was calculated.

In general, the results on resource use efficiency for wheat farmers in the study area imply that, inputs such as number of irrigation and fertilizer were underutilized, while other inputs such as agricultural chemicals, seed, labour, and machinery were over-utilized.

So that, farmers in the study area were failing to allocative their input resources in efficient manner, they could be reached output maximization either with less quaintly of over-utilized inputs or with more quantity of underutilized inputs.

The key finding is that, fertilizer was underutilized in zone $S_{1}$, while its over-utilized in zones $S_{2}$, and $S_{3}$, this mean that farmer intend to increase output through using more quantity of fertilized due to the soil salinity effects on wheat yield. Furthermore, the value of scale elasticity ${ }^{7}$ indicates that, wheat farmers in the study area could increase their wheat production by $10.54 \%$ on average, through reallocation of their resources. Moreover, soil salinity effects play a significant role in resources use efficiency in wheat production. Wheat farmers in different salinity zones have different scale elasticity values; these values were associated negatively with soil salinity level. The results suggest that production scale could be increased by $13.9,8.5$, and $5 \%$ on average in $S_{1}$, $\mathrm{S}_{2}, \mathrm{~S}_{3}$ zones, respectively.

TABLE V. RESOURCE USE EFFICIENCY INDICATORS

\begin{tabular}{|c|l|l|l|l|l|l|}
\hline \multirow{2}{*}{ Variables } & \multicolumn{3}{|c|}{ Total sample } & \multicolumn{3}{c|}{$\mathrm{r}$} \\
\cline { 2 - 7 } & $\mathrm{MVP}^{8}$ & $\mathrm{MFC}^{9}$ & $\mathrm{r}^{10}$ & $\mathrm{~S}_{1}$ & $\mathrm{~S}_{2}$ & $\mathrm{~S}_{3}$ \\
\hline $\begin{array}{c}\text { No. of } \\
\text { Irrigation }\end{array}$ & 102417 & 12796 & 8.00 & 10.85 & 6.40 & 3.67 \\
\hline $\begin{array}{c}\text { Agricultural } \\
\text { Chemicals }\end{array}$ & 7697 & 31395 & 0.25 & 0.30 & 0.21 & 0.14 \\
\hline Fertilizer & 658 & 564 & 1.17 & 1.46 & 0.98 & 0.60 \\
\hline Seed & 129 & 886 & 0.15 & 0.18 & 0.12 & 0.08 \\
\hline Labour & 7801 & 25000 & 0.31 & 0.38 & 0.27 & 0.17 \\
\hline $\begin{array}{c}\text { Mechanizati } \\
\text { on }\end{array}$ & 30013 & 45063 & 0.67 & 0.78 & 0.58 & 0.39 \\
\hline
\end{tabular}

Source: own elaboration from survey data (2017)

\section{Technical Efficiency of Wheat Farms in the Study Area}

The TE results are presented and discussed in the following section. Table VI shows the mean value of TE, which was classified with respect to salinity zones.

The technical efficiency level on average was declining as the salinity level increasing. Results present that farm located in $S_{1}$ zone is more technically efficient than once in $S_{3}$ zone by $11 \%$ this imply that, farmer in $S_{3}$ zone could increase their efficiency by $9 \%$ if soil salinity reduced within or less than $7.5 \mathrm{dSm}^{-1}$.

TABLE VI. TECHNICAL EFFICIENCY ESTIMATION

\begin{tabular}{|c|l|l|l|}
\hline $\begin{array}{c}\text { Soil salinity } \\
\text { level }\end{array}$ & Mean TE & Farm & Percentage (\%) \\
\hline $\mathrm{S}_{1}$ & 0.76 & 148 & 55 \\
\hline $\mathrm{S}_{2}$ & 0.73 & 79 & 29 \\
\hline $\mathrm{S}_{3}$ & 0.57 & 43 & 16 \\
\hline Total sample & 0.72 & 270 & 100 \\
\hline \multicolumn{3}{|c|}{ Source: own elaboration from survey data (2017) } \\
\hline
\end{tabular}

In general, Table VI shows that the mean value of technical efficiency of farms was $72 \%$, while Fig. 3 shows that about $48 \%$ of farmers have technical efficiency more than $80 \%$, and only about $2 \%$ of the farmer have technical efficiency less than $30 \%$.

\footnotetext{
${ }^{7}$ scale elasticity $=\sum r$

${ }^{8} M V P_{x}=M P P_{x} \times P_{y} . M V P_{X}$ is marginal value product of input $x$.

Output price represented by $P_{y}$.

${ }^{9} M F C_{X}$ is marginal factor cost of input $x$.

${ }^{10} r_{x}=\frac{M V P_{x}}{M F C_{x}} \cdot r$ is efficiency coefficient of input $x$.
} 


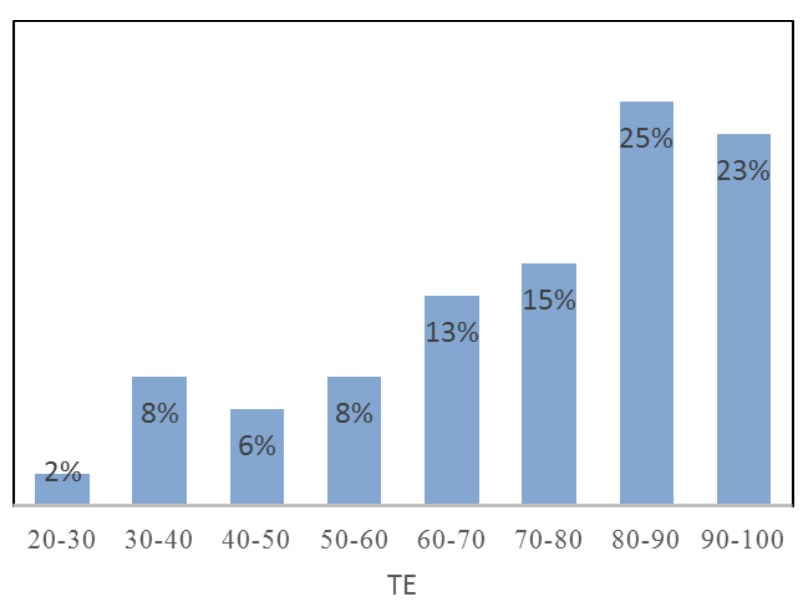

Figure 3. Percentage distribution of TE

Based on SFA approach and Cobb-Douglas production function, Fig. 4 presents the relationship between TE and wheat yield with the value of soil salinity threshold used was $7.5 \mathrm{dSm}^{-1}$. Yield varies across farms in the sample and their range of TE. The more efficient farmers gain more yield than those farmers who are technically less efficient. Despite this, it can be clearly seen that some farmers who achieve high level of TE in high salinity levels gain low yield from those who has the same or less level of TE in low salinity farms.

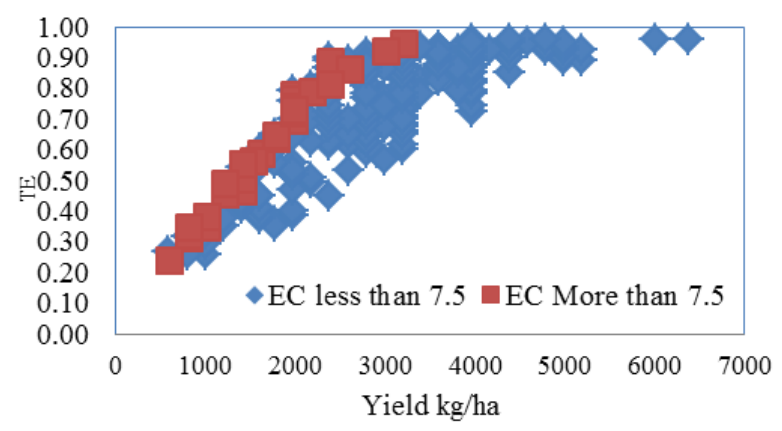

Figure 4. Yield and technical efficiency relationship

This result clearly indicates that reducing soil salinity at farm level will contribute to increase yield level for the same level of input use or less. Thus, one way to remove the inefficiency in wheat production and increase productivity in Iraq is improve efficiency of resources used in wheat production through reducing soil salinity at farm level. This can be done through investing in reclaimed land.

\section{CONCLUDING REMARKS AND IMPLICATIONS}

This research gives an analytical understanding on the salinity effects on resources use efficiency and productivity in irrigated wheat production system in Waist province, central of Iraq. Soil salinity hasmultisided impacts: The first impact is on the inputs side, in which farmers in salt-induced soil use more quantities of inputs compare with the farmers in the low salinity soil. Soil salinity causes different damages on each input. Some of these damages lead to reduce the productivity of that input. The second impact is on the production side in which farming in high salinity land lead to reduce wheat production by $50 \%$ in irrigated wheat system. Such results are affecting clearly farmer's livelihood. The last impact is unaccounted ones, in which salinity has negative externalities on environment such as downstream water pollution by unabsorbed quantities of fertilizer and agricultural chemicals given their massive use by farmers to mitigate the salinity level.

The comprehensive analysis of SFA shows the soil salinity impacts on resource use efficiency and productivity in the study area of Iraq. Based on SFA empirical results and with respect to scale elasticity wheat farmers in Wasit province can increase wheat yield by $10.54 \%$ on average through reallocation of their resources. There were two main sources of inefficiency and both are related to soil salinity, the first was EC of soil. If EC of soil is reduced less than $7.5 \mathrm{dSm}^{-1}$, this leads to reduce the technical inefficiency. The second source was the localization of the farm in which if farmer cultivated their wheat in reclaimed land, they will be more technically efficient. Farmers can increase wheat production through reallocated their resources in efficient way based on $r$ value, this true to some extent, excluding fertilizer in high salinity farm.

An average level of technical efficiency estimated through using SFA, was $72 \%$. Soil salinity has a clear impact on wheat yield and technical efficiency level, in which even some farmer in high salinity area reach their maximum TE, they could not reach yield value gained by less efficient farmers in low salinity area.

The empirical findings from this study suggest that, neither interdicting new innovations, nor increasing inputs use will not increase wheat production sustainably due to cumulative effects of salinity. Iraqi government should rehabilitate irrigation and draining systems, and increase price support of wheat. Additionally, reduce subsides of over utilized inputs and increase subsides of underutilized inputs.

\section{ACKNOWLEDGMENT}

The authors express their thanks to the International Center for Agricultural Research in the Dry Areas (ICARDA) and Arab Fund for Economic and Social Development (AFESD) for funding this research.

\section{REFERENCES}

[1] C. V. Moore, J. Snyder, and P. Sun, "Effects of Colorado River water quality and supply on irrigated agriculture," Water Resources Research, vol. 10, pp. 137-144, 1974.

[2] FAOSTAT Statistics Division. FAO. (2016). [Online]. Available: htt://faostat.fao.org

[3] B. Dhehibi, R. Telleria, R. A. Aw-hassan, S. H. Mohamed, F. Ziadat, and W. Wu, "Impacts of soil salinity on the productivity of al-musayyeb small farms in Iraq: An examination of technical, economic and allocative efficiency," Agricultural Economics Review, vol. 16, p. 42, 2015.

[4] A. Zowain, A. H. Hydera, S. H. Mohamed, R. Tellerla, A. Awhassan, and B. Dhehibi, "Iraq salinity project technical report 8," 2012.

[5] J. Torkamani and J. B. Hardaker, "A study of economic efficiency of Iranian farmers in Ramjerd district: An application of stochastic programming," Agricultural Economics, vol. 14, pp. 73-83, 1996. 
[6] M. Belloumi and M. S. Matoussi, "A stochastic frontier approach for measuring technical efficiencies of date farms in Southern Tunisia," Agricultural and Resource Economics Review, vol. 35, pp. 285-298, 2006.

[7] S. Thiruchelvam and S. Pathmarajah, "An economic analysis of salinity problems in the Mahaweli River system H irrigation scheme in Sri Lanka," Economy and Environment Program for Southeast Asia (EEPSEA), 1999.

[8] S. Mandal, K. Datta, B. Dayal, P. Minhas, and C. Chauhan, "Resource use efficiency in saline irrigated environment," Indian Journal of Agricultural Economics, vol. 60, 2005.

[9] MOP, “Annual abstract of statistics 2015-2016," IRAQ Ministry of Planning, 2016

[10] D. J. Aiger and G. G. Cain, "Statistical theories of discrimination in the labor market," Industrial and Labor Relations Review, vol. 30, pp. 175-87, 1977.

[11] W. Meeusen and J. B. Vanden, "Efficiency estimation from CobbDouglas production functions with composed error," International Economic Review, pp. 435-444, 1977.

[12] D. Ohajianya, "Resource use efficiency of land owners and tenants in food crop production in Imo State Nigeria," Journal of Sustainable Tropical Agricultural Research, vol. 17, pp. 26-30, 2006.
[13] D. Awunyo-vitor, C. A. Wongnaa, and R. Aidoo, "Resource use efficiency among maize farmers in Ghana," Agriculture \& Food Security, vol. 5, p. 28, 2016

[14] A. Fasasi, "Resource use efficiency in yam production in Ondo State, Nigeria," Agricultural journal, vol. 1, pp. 36-40, 2006.

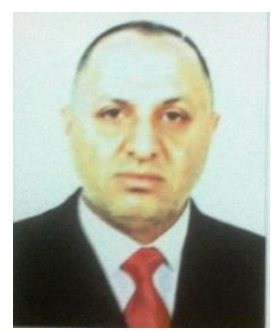

Mohammed J. Abdulradh was born in October 1973 in Maysan, Iraq. He got his B. S. in Agricultural Economics, University of Mosul, Iraq, 1996, MSc. In Natural Resource Economics, University of Queensland, Australia in 2012. He is now at the Department of agricultural economics, Collage of Agriculture, University of Baghdad, as a third year $\mathrm{PhD}$ student. His past careers are agricultural research at public works Agricultural Directorate of Maysan Province, Ministry of Agriculture in Iraq. His research interests are planning and following up of agricultural practices, monitoring agricultural investment and projects, and improving livelihoods and environment for agrarian community. 